\title{
Revisiting the guidelines and choice the ideal substitute for aortic valve endocarditis
}

\author{
Francesco Nappi $^{1}$, Sanjeet Singh Avtaar Singh ${ }^{2,3}$, Cristiano Spadaccio ${ }^{2,3}$, Christophe Acar ${ }^{4}$ \\ ${ }^{1}$ Department of Cardiac Surgery, North Cardiological Center, Saint-Denis, Paris, France; ${ }^{2}$ Department of Cardiac Surgery, Golden Jubilee National \\ Hospital, Glasgow, UK; ${ }^{3}$ University of Glasgow Institute of Cardiovascular and Medical Sciences, Glasgow, UK; ${ }^{4}$ Department of Cardiovascular \\ Surgery, Heart Institute, la Pitie Salpetriere Hospital, Paris, France \\ Contributions: (I) Conception and design: F Nappi; (II) Administrative support: None; (III) Provision of study materials or patients: F Nappi; (IV) \\ Collection and assembly of data: F Nappi; (V) Data analysis and interpretation: None; (VI) Manuscript writing: All authors; (VII) Final approval of \\ manuscript: All authors. \\ Correspondence to: Francesco Nappi, MD. Cardiac Surgery, North Cardiological Center, Saint-Denis, 36 Rue des Moulins Gémeaux, 93200 Saint- \\ Denis, France. Email: francesconappi2@gmail.com.
}

\begin{abstract}
Aortic valve replacement is the most commonly performed cardiac surgical operation worldwide for infective endocarditis (IE). Long-term durability and avoidance of infection relapse are the treatment goals. However, no detailed guidelines on prosthesis selection and surgical strategy are available. Management should be guided by a comprehensive evaluation of infection extension and its microbiological characteristics, the clinical profile of the patient and the risk of infection recurrence. We conducted a literature search of the PubMed database, EMBASE and Cochrane Library (through November 2019) for studies reporting to the use of biological substitutes in aortic valve endocarditis (AVE). Studies comparing long-term outcomes in the use of allogenic and autologous with conventional prostheses were investigated. Conventional mechanical or stented xenografts are the preferred choice for localized aortic infection. In cases of complex IE with the involvement of the root or the aorto-mitral continuity, the use of homografts are recommended, according to surgeon's and center experience. Homograft use needs to be balanced against the risk of structural degeneration. Prosthetic bioroot or prosthetic valved conduit with a mechanical or bioprosthetic valve are acceptable alternatives. The choice of aortic valves substitute and surgical strategy in IE is multifaceted. Principles guiding the selection of prosthesis and surgical approach rely on the longterm durability and the avoidance of infection relapse. A decisional algorithm considering the extension of the infection and its microbiological characteristics, the clinical profile of the patient and the risk of infection recurrence is provided. A multidisciplinary effort is required to achieve consistent outcomes.
\end{abstract}

Keywords: Aortic valve endocarditis (AVE); surgical aortic valve replacement; homograft; Ross procedure; guidelines

Submitted Feb 11, 2020. Accepted for publication Jul 09, 2020.

doi: 10.21037/atm-20-1522

View this article at: http://dx.doi.org/10.21037/atm-20-1522

\section{Introduction}

Current guidelines recommend aortic valve replacement (AVR) for infective endocarditis (IE) and have been widely adopted by the surgical community (1). The majority of patients in North America and Europe receive conventional mechanical or stented/stentless xenograft prostheses for surgical treatment of aortic valve endocarditis (AVE) (2-4); However, allogenic and autologous tissue have been advocated in selected cases (5-10). Inertia towards allogenic and autologous tissue probably stems from the lack of randomized clinical trials (RCTs) supporting observational studies. Several studies that noted benefits 
of aortic homografts and pulmonary autografts in IE were individually underpowered to highlight substantial differences in outcomes (11-13). Moreover, infection recurrence after AVR for IE is concerning. Thus, the optimal valve substitute in this setting has been debated for decades (2-18).

Aortic valve homograft and pulmonary autograft are ideal options for young patients, women with childbearing potential or patients with contraindications to anticoagulation $(5-11,15,16,19)$. Patient selection is crucial due to the caveat of increased early structural valve degeneration (SVD) $(5,20,21)$.

We reviewed the literature comparing different surgical strategies for treatment of AVE including our own experience and discuss current evidence-based practice whilst proposing an algorithm to guide valve choice.

\section{Methods}

We included all randomized controlled trials, significant retrospective studies and sub-studies evaluating outcomes of patients undergoing aortic valve replacement for endocarditis. The literature search through PubMed from its inception up to $5^{\text {th }}$ November 2019 included the following keywords with the related MeSH terms: "endocarditis", "aortic valve", "heart valve prosthesis", "allograft", "autograft", "cardiac surgery", "aortic valve replacement". Guidelines, professional society recommendations, registries, editorials, case series, prior systematic reviews were considered as additional references. Four thousand one hundred eleven patients for xenograft prosthetic (XP), 2,454 for cryopreserved aortic homograft $(\mathrm{CAH}), 665$ for the mechanical prosthetic (MP), and $<200$ for Ross operation and aortic valve repair extracted and evaluated (Tables $S 1, S 2)$.

\section{Results}

\section{Homograft replacement for AVE}

The survival benefits associated with the use of the aortic homograft for aortic valve replacement were established in a landmark paper from the Brisbane group and Harefield group almost 40 years ago $(5,6,9)$. Allogenic tissue is more likely to be used in patients with active endocarditis and the most severely infected field $(5-10,12,13)$. The Harvard group reported a significant increase in the proportion of patients treated with allogenic tissue when abscess formation occurred ( $67 \%$ vs. $41 \%$ for mechanical valve and $30 \%$ for xenograft valves, $\mathrm{P}<0.001$ ) or when there is infection with methicillin-resistant Staphylococcus (26\% vs. $13 \%$ for mechanical prosthesis and $12 \%$ for xenograft) (8).

Several studies have reported substantially inferior infection relapse rates with aortic homograft substitutes. Fukushima et al. (9) showed low rate $(0.2 \%)$ of re-infection at 30 days and $5.5 \%$ rate of late infection with a median time of 5 years ( 4 months to 16 years) post-homograft implantation. Arabkhani et al. (10) revealed excellent results at up to 27 years postoperatively using aortic homografts, with a low incidence of reoperation for re-infection (2.2\%). Allogenic tissues have favorable responses to antibiotic treatment [effective in $21-25 \%$ of cases $(7,8)$ ]. Musci et al. (22) reported 221 homograft aortic root replacements in 1,163 patients with active endocarditis and peri-annular abscess highlighting a lower rate of recurrence of infection $(5.4 \%)$ in native valve endocarditis (NVE) and prosthetic valve endocarditis with a 10 -year freedom from reoperation rate of $92.9 \% \pm 3.2 \%$ and $92.1 \% \pm 2.5 \%$, respectively. Early mortality was $16 \%$ (NVE) and $25 \%$ for (PVE) with improved 10-year survival in NVE (47\% vs. $35 \%)$. More than $25 \%$ of deaths were intraoperative, highlighting the operative complexity among critically ill patients. Yankah et al. (23) showed excellent clinical performance and durability with low reinfection and a late mortality rate of $7.9 \%$. Patient survival was $97 \%$ and $91 \%$ at 1 - and 10 -year, respectively. Perrotta et al. (24) demonstrated a 5-year cumulative survival of $88 \%$ in homografts versus $66 \%$ in prostheses in PVE. Kim et al. (8) showed lower risk of reinfection within 1-year in homograft recipients.

Homograft usage has decreased over time for first-time aortic valve replacement (9.4\% to $5.6 \%)$ and reoperations ( $37.5 \%$ to $28.5 \%$ ) according to the STS database [2005-2011] (17) (Figure 1). It is more commonly used in reoperations compared to primary interventions $(32.2 \%$ vs. $7.0 \%, \mathrm{P}<0.0001)$ for valve $(14.6 \%)$ and root replacements $(53.2 \%)(15)$. The benefit of homografts in IE remains debatable because of the lack of RCTs (2,3,5-10,15-18).

No significant differences in overall mortality and infection recurrence have been described compared to mechanical or biological substitutes in IE $(2,3,8,14,18)$. Klieverik et al. (14) reported similar recurrent endocarditis rates in homograft recipients compared to mechanical valves with lower freedom from reoperation $(76 \%$ vs. $93 \%$, respectively). Sabik et al. (12) reported a $95 \%$ freedom from recurrent infection exceeding 2 years and an operative mortality of $3.9 \%$ in 103 patients with prosthetic valve 


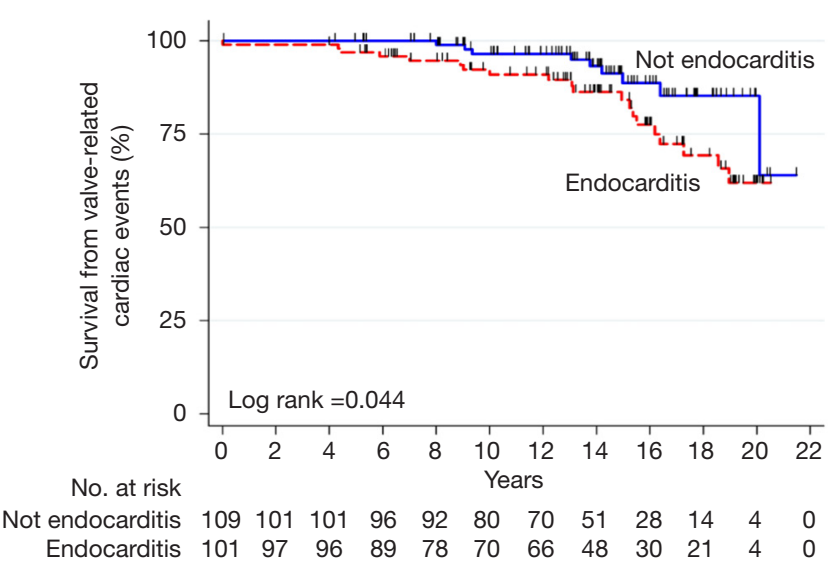

Figure 1 Survival of aortic homograft from valve-related cardiac events with regards to preoperative etiology. Reproduced with permission from Nappi et al. (7).

endocarditis (PVE).

Bekkers et al. (20) reported freedom from homograft root re-operation for SVD of $59.3 \%$ after 14 years with a $3.84 \%$ reoperation rate for re-infection at 14 years. Kowert et al. (21) described a homograft explantation rate of $24.8 \%$ (90/363 patients) due to infection (15\%) or SVD $(85 \%)$ at 15.5 years. Although re-operations are technically demanding, they can be performed with satisfying results (7-10,20,21); however, mortality was increased posthomograft infections $(7,21)$.

We used the homograft for aortic and mitral valve disease in $56.2 \%$ and $21 \%$ of patients with abscess formation $(5,25-28)$ (Figure 1). Sometimes, a double homograft is used in aggressive IE with extension to the aorto-mitral junction and mitral valve (25-28). We performed monobloc implants in two-thirds of recipients, and a separate bloc with partial mitral homograft insertion in the remaining $(5,27,28)$. The technique of implant provided good results even with fragile tissues (28) .

The limited use of allogeneic tissue may be due to the enthusiasm that antibiotic therapy alone is building for some cases of PVE (29), previously considered as a clear indication for surgery (1). The inclination to use allogeneic tissues in extensive infection of heart structure, either in native or prosthesis valve disease, is supported by Steffen et al. (30). The authors have shown that CAH has antibacterial activity despite long-term conservation for 5 years. Antimicrobial combinations (gentamicin, piperacillin, vancomycin, metronidazole, amphotericin $B$, flucloxacillin, meropenem, tobramycin and colistin) applied during allogenic tissue processing have a significant influence on their infection resistance. Homograft tissue of ascending aortic revealed a significantly enhanced bacterial resistance against staphylococcal bacteria (S epidermidis and $S$ aureus) with less bacterial contamination compared to homograft aortic valves. More effective resistance was found against $P$ aeruginosa using flucloxacillin and $E$ coli with meropenem and colistin (31). Application of antibiotic after thawing $\mathrm{CAH}$ led to a significant decrease in the recurrence of infections (32); a phenomenon not demonstrated in conventional prosthesis or Dacron graft, although the risk of vascular graft infection is reduced by pretreating the prosthesis with antibiotics (33). Indeed, the antibiotic/fibrin compound showed a favorable effect of delayed release of antibiotics in the early prevention of the relapse of infection (33). Furthermore, new suggestions are regarding more effective concentrations of $\beta$-lactam antibiotics which may enhance this action, providing additional immunity to infection recurrence (33). The favorable response of allogeneic tissue to antibiotic treatment is already documented in the pivotal series where $\mathrm{CAH}$ was successfully treated medically (from $21 \%$ to $25 \%$ ) $(5,9,10)$.

\section{Ross procedure for $A V E$}

The Ross procedure is of limited use in endocarditis $(11,34)$. The increased surgical complexity alongside the potential for long-term failure of 2 valves (aortic and pulmonary) has been discouraging, with a 3 -fold increase in operative mortality compared to conventional aortic valve replacement (35). However, a volume-outcome relationship has been reported with lower mortality in highvolume centers $(0.3-1.1 \%)(6,8)$. This rekindled the role of the pulmonary autograft in management of AVE, when avoiding prosthetic material is necessary, increased risk of relapsing infection or in women of childbearing age (36). The Ross operation has shown optimal long-term results with low rates of valve-related complications for recurrent endocarditis (Figure 2). Patients with life expectancy $>15$ years, active lifestyle and no severe comorbidities should be referred to centers with high surgical experience $(36,39)$.

\section{Conventional biological and mechanical prosthesis}

A retrospective cohort analysis of 4,253 patients (40) aged 50-69 years, including 1,001 propensity-matched patients showed no significant difference in 15 -year survival $(60.6 \%$ vs. $62.1 \%$, hazard ratio 0.97 ; $95 \%$ CI, $0.83-1.14)$ and stroke 


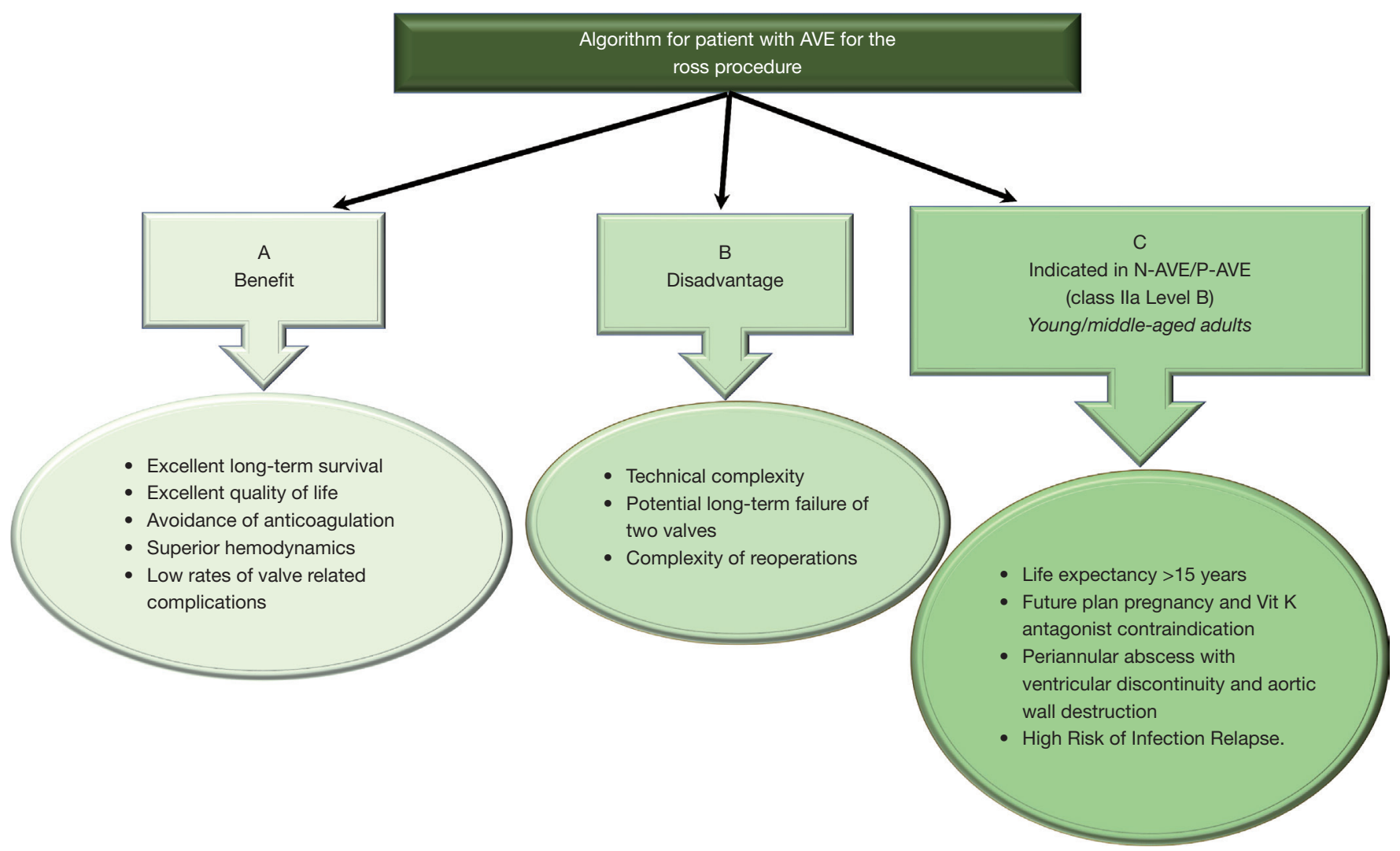

Figure $2(\mathrm{~A}, \mathrm{~B})$ Benefit and disadvantages of the Ross procedure in patients with AVE; $(\mathrm{C})$ indications for the Ross procedure in AVE. This proposed algorithm remains to be further validated and supported by guidelines and position papers of professional societies (35-39).

(7.7\% vs. $8.6 \%$, hazard ratio $1.04 ; 95 \%$ CI, $0.75-1.43$ ) among bioprosthetic valve and mechanical prosthesis group. Recipients of bioprosthetic valves had a higher incidence of reoperation $(12.1 \%$ vs. $6.9 \%$, hazard ratio $0.52 ; 95 \%$ CI, 0.36-0.75) but less major bleeding (6.6\% vs. $13.0 \%$, hazard ratio $1.75 ; 95 \% \mathrm{CI}, 1.27-2.43)$. Therefore, stented xenografts may be suitable in recipients aged 50 to 69 years. The Washington University group studied 309 patients with aortic valve operations for endocarditis [1996-2012]. Procedures included repair (6\%), mechanical (26\%), bioprosthetic (62\%), and homografts (6\%). Before 2000, mechanical valves were used in $50 \%$ of patients compared to $14 \%$ since 2009 (41). STS Database analysis17 showed a progressive shift towards biological valves in both primary operations (NVE) $(8,421$ patients, $73 \%)$ and reoperation (PVE) (3,139 patients, 27\%) from 2005 onwards at the expense of mechanical valves and homografts (Figure 3). The latter was used in only $7 \%$ of primary operations and $32 \%$ of reinterventions (17).

\section{Stented/non-stented xenograft}

The major concern for xenografts is the increased risk of SVD. A recent meta-analysis including all types of available aortic xenograft (porcine and pericardial) revealed that SVD commonly starts 8 years post-surgery, exponentially increasing after 10 years, which is comparable to a homograft $(42,43)$.

Carpentier-Edwards Perimount stented aortic (CEP) (Edwards Lifesciences Inc., Irvine, California, USA) pericardial valve is widely used in North America and Europe. In one study involving 2,559 patients, $13.9 \%$ of recipients were $<60$ years and 111 (4\%) had IE. The authors reported actuarial freedom from SVD at 20 years of $48.5 \%$, and an expected valve durability (median survival time without SVD) of 19 years. Freedom from recurrent endocarditis was $88.8 \%$ at 20 years (44). The Cleveland Clinic group included 12,569 patients (mean follow-up duration $>5.8$ years) with CEP implanted in the aortic position. Three hundred fifty-four prostheses were 

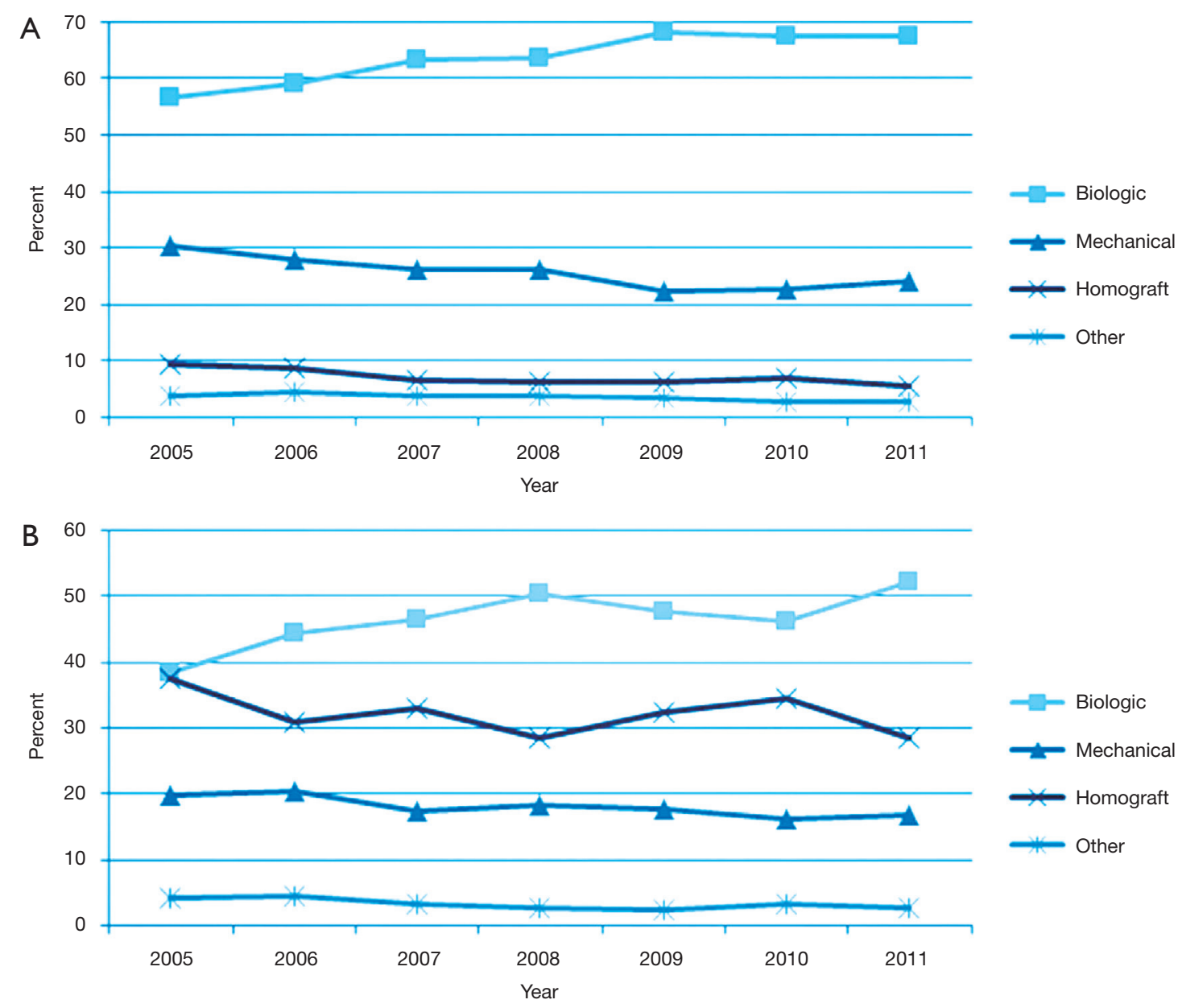

Figure 3 Trend representing the use of substitutes for AVR in endocarditis from 2005 to 2011 in USA (STS database). (A) Native aortic valve endocarditis and (B) prosthetic valve endocarditis. The $\mathrm{P}$ value for the usage trends in both groups was $<0.001$. (biologic $=$ squares; mechanical $=$ triangles; homograft $=\mathrm{x}$; other $=$ star. $)$. Reproduced with permission from Savage et al . (17).

explanted during follow-up, $41 \%$ for endocarditis and $44 \%$ for SVD. The study reported an actuarial freedom from SVD rate of $45 \%$ (95\% CI, 39 to 52) for patients $<60$ years and $8.1 \%$ (95\% CI, 6.7 to 9.7) for patients 60 to 80 years old at 20 years. Four hundred fifty patients $(3.8 \%)$ received bioprostheses for IE with an overall probability of explantation for endocarditis at 20 years of $1.4 \%$ (45).

Long-term durability of CEP was better than expected in younger patients. Bioprosthetic valves are recommended in young patients with AVE who wish to avoid anticoagulation (1). It is important to implant large bioprostheses $(>21 \mathrm{~mm})$ for future potential transcatheter valve-in-valve procedures in case of SVD. Transcatheter interventions on small-sized valves should be avoided due to the potential risk of early attenuated leaflet motion, transcatheter heart valve thrombosis and SVD (46).

No significant difference in freedom from reoperation at 8 years was found when Perimount and Hancock II valves were compared (98\% and $97 \%$ respectively) with low endocarditis reoperation rates in both (47).

Newer generation pericardial valves have limited longterm follow-up and could potentially be less reliable during infection. Mitroflow bioprosthesis (models-12A/ LX; LivaNova), showed a mean time to SVD of $3.8 \pm$ 1.4 years (48). St Jude's Trifecta aortic bioprosthesis, showed 6 -year actuarial freedom from SVD and freedom from reoperation of $95 \%$ and $96 \%$, respectively (49), although some early failure reports were described (50).

Schaefer et al. (4) compared the CEP to Sorin Freedom Solo Stentless aortic valve (SFS) (LivaNova PLC, London, 
UK) in 154 consecutive patients with NVE with follow-up duration exceeding 6 years and noted significant reduction in SVD (0\% vs. $5.2 \% ; \mathrm{P}=0.04)$ and valve explantation ( $1.3 \%$ vs. $9.1 \%$; $\mathrm{P}=0.04)$ in CEP group vs. SFS group. SFS showed hemodynamic superiority with significant lower postoperative peak and mean pressure gradients compared to CEP group. Survival after NVE was inferior with a significant impact of re-do surgery on survival (HR: 7.63; 95\% CI: $1.65 \pm 35.25, \mathrm{P}=0.009$ ). Age and preoperative NVE were associated with an increased risk of death during follow-up with hazard ratios of 2.23 and 2.56, respectively. Reports on the use of pericardial valves (SFS) for NVE are scarce with limited patients and comparisons $(51,52)$.

\section{Mechanical prosthesis}

There are no randomized studies comparing mechanical $v s$. bioprosthetic valves in endocarditis $(2,4,8,14,53)$. The inferior survival benefit associated with bioprosthetic valves were established by a French multicenter AVE study (53) where patients underwent homograft (16\%), bioprosthetic (19\%), or mechanical (65\%) replacement with 5-year follow-up. The advantage reported in the mechanical group was likely related to the younger age and reduced comorbidities of the patients in this group. The Stanford group (3) studied the impact of valve selection to treat leftsided endocarditis. Between 1964 and 1995, 306 patients underwent left-sided valve replacement for NVE (68\%) or PVE (32\%). Valve replacement included aortic only in $62 \%$, mitral only in $29 \%$, and aortic and mitral in $9 \%$. Mechanical valves were initially favored (61\% of cases from 1968-1976). Bioprosthetic valves were used almost exclusively (98\%) in the following decade. From 1987 to 1995, the valve choice varied, mechanical (25\%), bioprosthetic $(65 \%)$, and homografts (10\%). Operative mortality was $18 \%$, regardless of the valve type used. Long-term survival was substantially higher in NVE compared to PVE. The authors showed equivocal risk of reoperation for infection relapse among mechanical (2.1\%) and bioprosthetic valves $(2.3 \%)$ at 5 years and a slightly increased risk for mechanical prostheses $(0.5 \%)$ compared to stented xenografts $(1.1 \%)$ beyond 5 years. Similar long-term survival excluding operative death was noted between mechanical (62\% and 46\%) vs. bioprosthetic prosthesis ( $61 \%$ and $41 \%)$ at 10 and 20 years, respectively.

Kim et al. (8) preferentially used mechanical prosthesis in endocarditis complicated by abscess formation. This trend continued if simultaneous involvement of mitro- aortic curtain and mitral valve (mechanical valves in $38 \%$ $v s$. of patients compared to xenograft 18.7) were present $(8,54)$. The data coincided with David et al. (2), who reported excellent results when mechanical valves were used with synthetic patches or prosthetic valve conduits in complicated AVE.

\section{Future perspectives}

The increasing use of cardiac implantable electronic devices and the recent TAVR expansion have significant implications for potential IE on these percutaneously implanted devices and the infection risk profile of the patients undergoing these procedures.

The use of TAVR is not indicated in endocarditis. The use of sutureless valves may be an alternative, especially in cases of endocarditis in high-risk patients in which reduced operative times are desirable. However, the current experience and results on the benefit of sutureless valves in AVE are scarce (55-57).

\section{Discussion}

The incidence of IE is 3-10 per 100,000 ranging from $35 \%$ (2) to $39.1 \%$ (58) for native aortic valve involvement and from $56 \%$ (59), to $64.4 \%$ (58) in patients with previous aortic valve surgery. In AVE, the surgeon has 2 dilemmas: (I) the timing of the operation (II) and choice of the valve substitute depending on the extent and position of the infectious lesion. Timing for surgery of AVE is conditioned by uncontrolled infection, risk of embolism and heart failure (Figures 4-6).

\section{Choice of substitute and extension of IE}

Patients with one or more aortic valve leaflet(s) involvement at risk of bacterial embolism (large vegetation $>10 \mathrm{~mm}$ ), and/or with left ventricular dysfunction, should be offered surgery. Successful outcomes encompass the following general principles: (I) restoration of aortic valve competence; (II) restoration/preservation of annular structural integrity; (III) absence of residual infection postsurgery. The general principle of a radical debridement of the entire infected area applies and intraoperative TEE is mandatory for AVE.

Aortic valve replacement is the most common surgical operation performed for IE. Aortic valve repair may be performed in localized infections with uncomplicated 


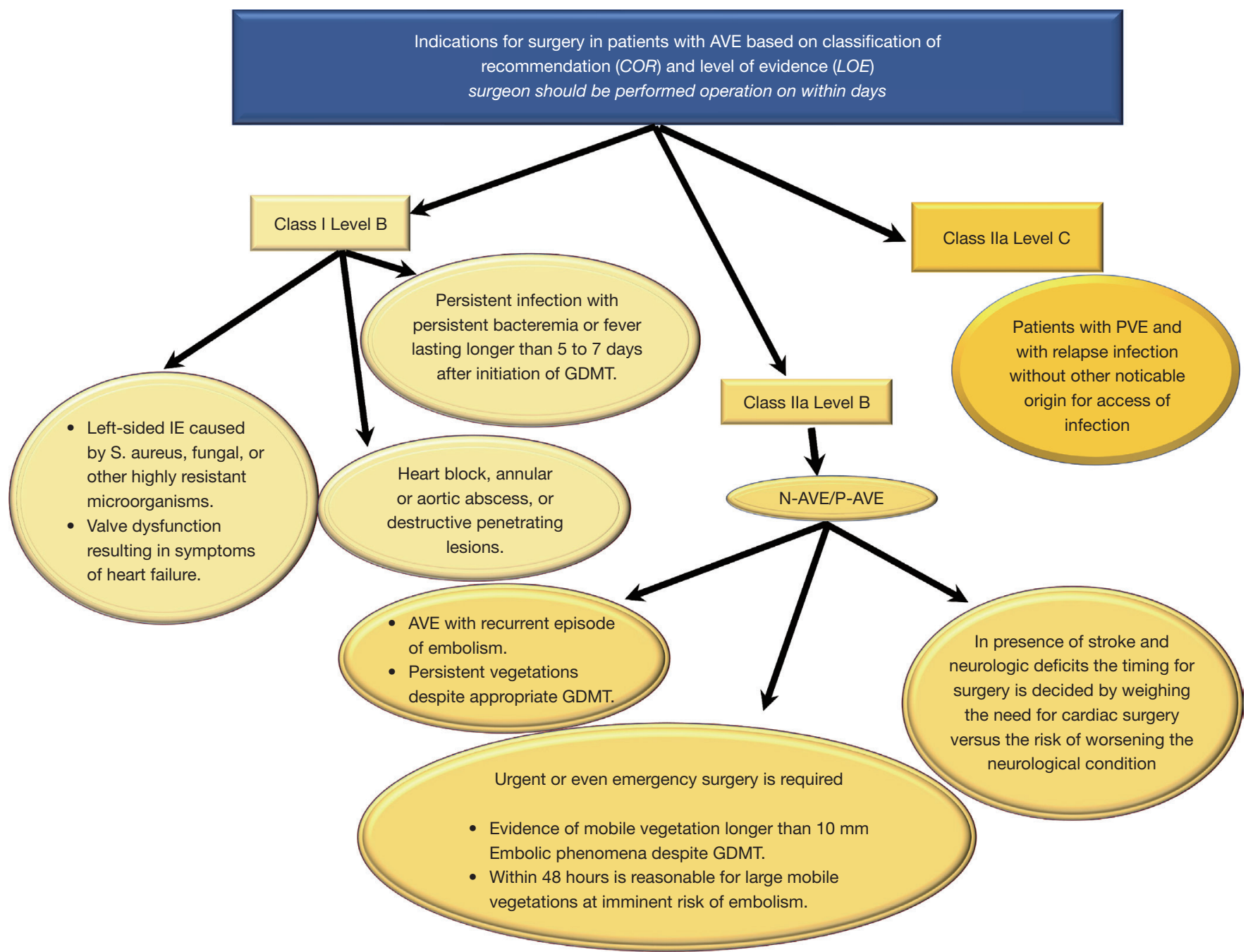

Figure 4 General features of intraoperative management of patients with AVE. AVE, aortic valve endocarditis; COR, Classification of recommendations; GDMT, guide direct medical therapy; LOE, level of evidence; IE, infective endocarditis; N-AVE, native aortic valve endocarditis; P-AVE, prosthetic aortic valve endocarditis (29), (https://cdn.amegroups.cn/static/application/5ac1256ace28d0f984e03842d31 29217/10.21037atm-20-1522-1.pdf).

NVE of the aortic valve (60) (Class I Level B) caused by highly sensitive streptococci treated for 2-week with antibiotic therapy and involving the mitral valve as primary localization $(26,27)$. It has a high re-operation rate despite being limited to experienced surgeons $(60,61)$.

For localized infections of the native aortic valve (Class I Level B), aortic valve replacement remains the most effective surgical method for several categories of patients. Long-term durability and avoidance of re-infection is the treatment goal. Yet, no precise guidelines on prosthesis selection exist, and the choice of surgical strategy for aortic IE remains a "dark art" $(2,3,8,16)$. Many surgeons prefer conventional mechanical or stented xenografts alone or combined with polyester or pericardial patch when reconstruction of the annulus is required (15-18) (Class IIa Level B) (16). The choice of conventional valvesmechanical or tissue prostheses-is guided by the following criteria: age, life expectancy, comorbidities, and expected compliance with anticoagulation. It is reasonable to avoid the use of conventional mechanical valves in patients with any intracranial bleeding or those who have suffered a major stroke (Class IIa Level C) (16).

For extended infections, aortic root replacement and reconstruction of regional contiguity is the recommended 


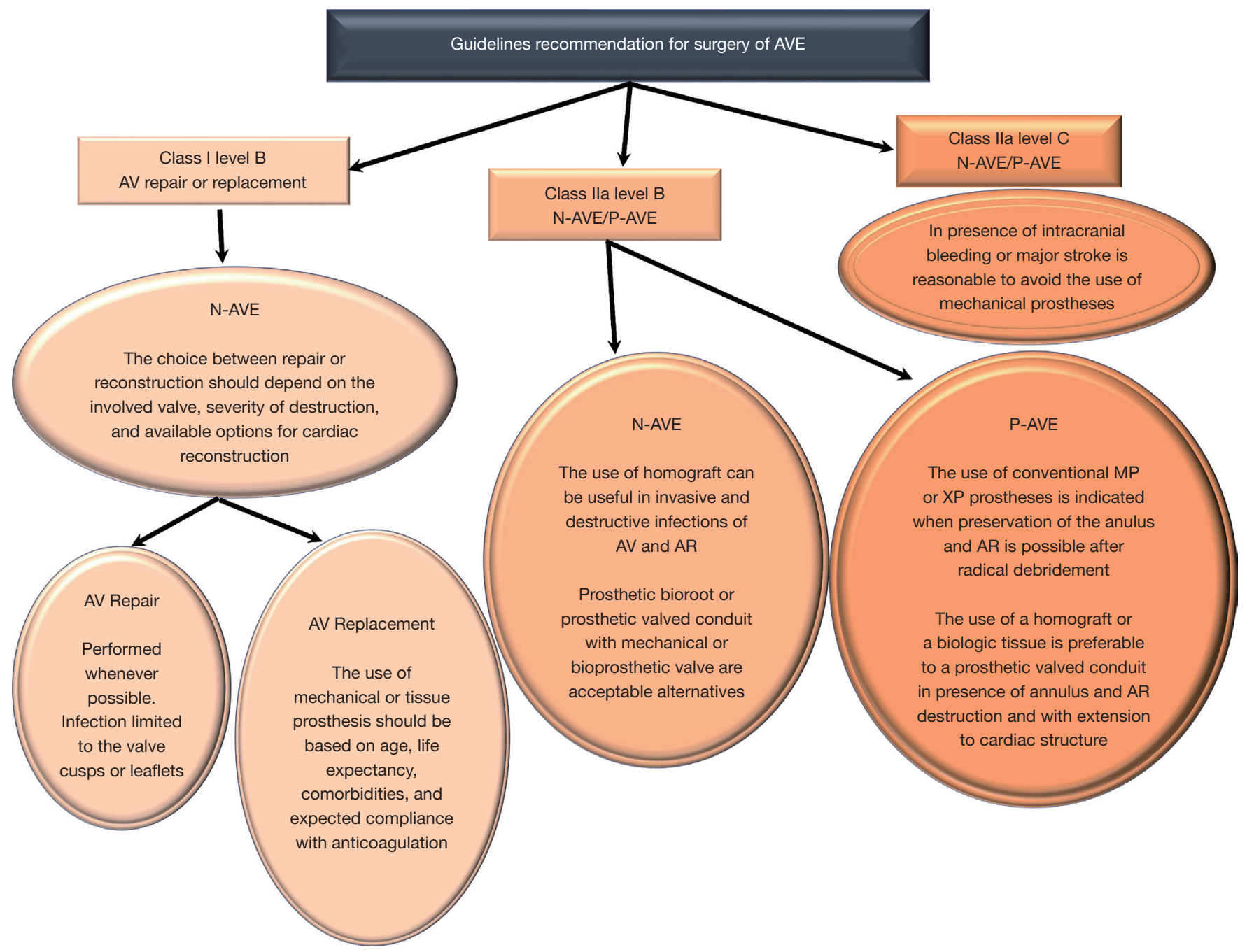

Figure 5 Specific assessment in surgical management of AVE. Abbreviation in Figure 4 (2-18,20-24), (Supplementary Material). (https://cdn. amegroups.cn/static/application/44b211ddc4e092b86fdb145d78229c07/10.21037atm-20-1522-2.pdf).

approach. Complicated aortic IE may present with severe aortic annular destruction, annular abscess and colonization of infected foci in contiguous structures (e.g., aortic root). In the presence of peri-annular abscess formation and mitro-aortic discontinuity, conventional mechanical or stented xenografts are used in combination with synthetic patches for both NVE and PVE $(2,8,15-18,53)$ (Class IIa Level B) (16).

The use of homograft is recommended for root reconstruction by professional societies based on large observational studies that have reported beneficial outcomes $(12,13,15-18)$. Nonetheless, the choice of prosthetic bioroot or prosthetic valved conduit with a mechanical or bioprosthetic valve are considered acceptable alternatives but it should be guided by the surgeon's experience $(2,3,12,13,15-18)$ (Class IIa Level B) (16).

Currently, the clinical benefits of using the homograft in IE operation are well established as the cornerstone of modern surgery for endocarditis (5-11,22-24). Evidence suggests that homograft usage to replace the aortic valve and root in NVE and PVE is associated with further improvements in late outcomes $(5-10,12,13,17,22-24,62,63)$. The benefits of allogenic tissue are applicable patients with a high-risk of recurrence, such as those with active infection and negative culture, fungal pathogens or HACEK group involvement, often evident within the first post-operative decade (7-9,11,22-24). In the presence of aggressive pathogens that have colonized a prosthetic valve causing 


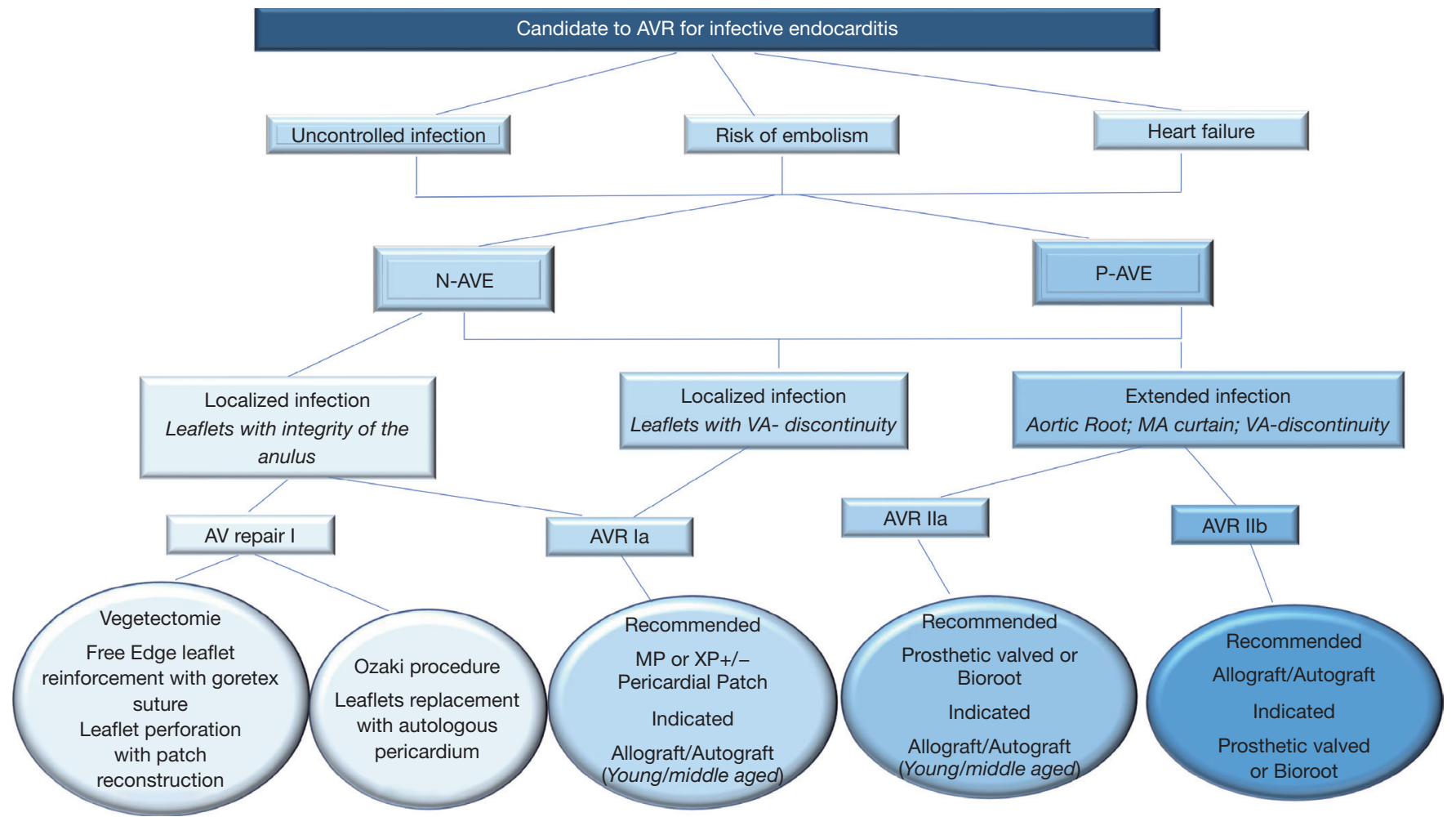

Figure 6 Algorithm to assess the candidate for surgical AVR in AVE.

annular destruction and invasion outside the aortic root, the use of an allograft or a biologic tissue root is preferable to a prosthetic valved conduit for aortic valve replacement and root reconstruction. Conversely, in patients with PVE when the surgeon is faced with an aortic annulus and root that are preserved, it is reasonable to use a conventional mechanical or XP valve after radical debridement (Class IIa Level B) (16).

Early SVD remains a major drawback for allogenic tissue use in younger patients $(5,9-11,14,20,21)$. No observational studies on durability have shown a difference in clinical outcomes compared to conventional prosthesis $(4,7,9-11,44,45,47)$. The ubiquity of bioprosthesis and the less technically-demanding implantation support its use $(2,4,41,44,45,47)$.

Our analysis revealed that the superiority of homograft for AVE did not translate into a significant survival benefit at 15 years compared to conventional prosthesis (7,26-28). The dogma of early SVD, higher reoperation risk and survival is both intuitive and biologically plausible. It is indirectly supported by studies that show higher morbidity and worse survival among patients undergoing reoperations for homograft AVR $(18,20,21)$. Although there is a clear risk of redo operation for severe aortic valve calcification and aortic root of homograft compared to that conventional prosthesis, in-hospital mortality remains $2-5.5 \%$ in the elective setting $(7,9,10)$ that is comparable to other prosthesis $(2,3,8,18,41)$. However, homograft failure is likely to result in fatal cardiac events, in emergency surgery either for SVD or relapse of infection.

Based on current evidence, we propose four algorithms for the choice of valve for surgery of AVE (Figures 2,4-6). We considered the most important anatomic and technical determinants for the choice of valve substitute, alongside the clinical characteristics of the patient. Factors to consider include risk of embolization, durability, risk of infection recurrence, and severity of infective extension (in relation to its primary location). Immunological, histopathological and microbiological characterization of the target infective lesion is crucial when considering a homograft and autograft due to the living nature of this prosthesis $(5-11,37,38,63-68)$.

\section{Area of uncertainty}

In the future, the use of allogenic tissue preserved at $4{ }^{\circ} \mathrm{C}$ which improves immunological and inflammatory 
response, instead of cryo-preservation, will allow better physiological integration of valvular substitutes and cardiovascular structure, thereby improving long-term durability and clinical outcomes (65-69). We are unaware of any randomized trials that have compared the use of aortic homograft with decellularized allograft (DAVA) for AVE, and it is unlikely that such a trial will be conducted. Therefore, the current recommendation for the use of DAVA in the treatment of AVE is based on observational data $(70,71)$. The use of DAVA $(n=42)$ was compared with standard cryopreserved homograft $(\mathrm{CAH})(\mathrm{n}=29)$ and the rate of patients who had AVE was equivalent (DAVA 26\% vs. CAH 21\%, respectively). Freedom from reoperation at 10 years was $51 \%$ in recipients of DAVA compared with $80 \%$ for those who received a CAH (95\% CI, 34-76\% vs. $95 \% \mathrm{CI}, 60-100 \% ; \mathrm{P}=0.06)$. At 10 -year survival rates were $76 \%$ in patients who had a DAVA compared to $57 \%$ whereas the valve substitute was a CAH (95\% CI, 61-93\% vs. 95\% CI, 38-79\%; $\mathrm{P}=0.09)$ (71). Although evidence suggested that sterilization of decellularized valves could have a detrimental effect on the durability of cryopreserved allogenic tissue (72), similar fibrosis and calcification are observed in failed DAVA and CAH (70). Furthermore, a difference between the various modalities of the decellularization process in the preparation of the DAVA with different results at the follow-up is described. As a matter of fact, da Costa (72) reported a $98 \%$ freedom from reoperation at an average of 19 months of follow-up while Helder had a rate of $92 \%$ at 5 years outcomes (71).

\section{Guidelines}

The Society of Thoracic Surgeons (15) assigned Class I and IIa classifications with a Level of Evidence B to the use of a conventional mechanical or stented XP if radical debridement is carried out and the valve can be anchored to healthy and strong tissue. Class IIa, Level of evidence $\mathrm{B}$ is also assigned to the use of homograft. The choice of allogenic tissue is considered reasonable for native and prosthetic AVE particularly with periannular abscess and extensive annular or aortic wall destruction requiring aortic root replacement or reconstruction, as well as in cases of extensive aorto-ventricular discontinuity. The AATS 2016 guidelines $(16,73)$ echo these recommendations for the use of allogenic tissue in destructive native or prosthetic aortic valve IE, with indicated surgery of aortic root; however, the choice of prosthetic bioroot or prosthetic valved conduit with a mechanical or bioprosthetic valve are considered acceptable alternatives although it should be guided by the grade of surgeon's training and experience (Class IIa, Level B).

\section{Conclusions}

The guidelines and position papers of professional societies advise that both recommendations for the use of conventional valves or homografts are categorized as Class I and II. The reason is because there is opposing evidence and/or a divergence of viewpoints related to the benefit and efficacy of a procedure or treatment. The benefits and efficacy of aortic homograft are less well established by evidence and opinions. It is categorized as Class IIb because the data was derived from a single randomized trial or non-randomized studies (Level of evidence B). One of the reasons for the infrequent use of allogenic tissue is that the excellent clinical outcomes associated with their use in the field of AVE that has been reported in observational studies have not been replicated in the randomized, controlled trials. There is a concern that observational studies can be biased in favor of homografts by unmatched confounders related to the unmeasurable and incomparable findings of the operating surgeons.

The scarcity of robust clinical evidence still hampers our understanding of IE management.

\section{Acknowledgments}

Funding: None.

\section{Footnote}

Conflicts of Interest: All authors have completed the ICMJE uniform disclosure form (available at http://dx.doi. org/10.21037/atm-20-1522). FN serves as an unpaid editorial board member of Annals of Translational Medicine from Feb 2017 to Jan 2021. The other authors have no conflicts of interest to declare.

Ethical Statement: The authors are accountable for all aspects of this manuscript in ensuring that questions related to the accuracy or integrity of any part of the work are appropriately investigated and resolved. As a review article, explicit ethical approval was not required.

Open Access Statement: This is an Open Access article distributed in accordance with the Creative Commons 
Attribution-NonCommercial-NoDerivs 4.0 International License (CC BY-NC-ND 4.0), which permits the noncommercial replication and distribution of the article with the strict proviso that no changes or edits are made and the original work is properly cited (including links to both the formal publication through the relevant DOI and the license). See: https://creativecommons.org/licenses/by-nc-nd/4.0/.

\section{References}

1. Nishimura RA, Otto CM, Bonow RO, et al. 2017 AHA/ ACC Focused Update of the 2014 AHA/ACC Guideline for the Management of Patients With Valvular Heart Disease: A Report of the American College of Cardiology/ American Heart Association Task Force on Clinical Practice Guidelines. Circulation 2017;135:e1159-95.

2. David TE, Gavra G, Feindel CM, et al. Surgical treatment of active infective endocarditis: a continued challenge. J Thorac Cardiovasc Surg 2007;133:144-9.

3. Moon MR, Miller DC, Moore KA, et al. Treatment of endocarditis with valve replacement: the question of tissue versus mechanical prosthesis. Ann Thorac Surg 2001;71:1164-71.

4. Schaefer A, Dickow J, Schoen G, et al. Stentless vs. stented bioprosthesis for aortic valve replacement: A case matched comparison of long-term follow-up and subgroup analysis of patients with native valve endocarditis. PLoS One 2018;13:e191171.

5. O'Brien MF, Harrocks S, Stafford EG, et al. The homograft aortic valve: a 29-year, $99.3 \%$ follow up of 1,022 valve replacements. J Heart Valve Dis 2001;10:334-44; discussion 345.

6. Yacoub M, Rasmi NR, Sundt TM, et al. Fourteen-year experience with homovital homografts for aortic valve replacement. J Thorac Cardiovasc Surg 1995;110:186-93; discussion 193-4.

7. Nappi F, Nenna A, Petitti T, et al. Long-term outcome of cryopreserved allograft for aortic valve replacement. J Thorac Cardiovasc Surg 2018;156:1357-65.e6.

8. Kim JB, Ejiofor JI, Yammine M, et al. Are homografts superior to conventional prosthetic valves in the setting of infective endocarditis involving the aortic valve? J Thorac Cardiovasc Surg 2016;151:1239-48.e2.

9. Fukushima S, Tesar PJ, Pearse B, et al. Long-term clinical outcomes after aortic valve replacement using cryopreserved aortic allograft. J Thorac Cardiovasc Surg 2014;148:65-72.e2.

10. Arabkhani B, Bekkers JA, Andrinopoulou ER, et al.
Allografts in aortic position: Insights from a 27-year, single-center prospective study. J Thorac Cardiovasc Surg 2016;152:1572-9.e3.

11. El-Hamamsy I, Eryigit Z, Stevens LM, et al. Longterm outcomes after autograft versus homograft aortic root replacement in adults with aortic valve disease: a randomised controlled trial. Lancet 2010;376:524-31.

12. Sabik JF, Lytle BW, Blackstone EH, et al. Aortic root replacement with cryopreserved allograft for prosthetic valve endocarditis. Ann Thorac Surg 2002;74:650-9; discussion 9.

13. Lytle BW, Sabik JF, Blackstone EH, et al. Reoperative cryopreserved root and ascending aorta replacement for acute aortic prosthetic valve endocarditis. Ann Thorac Surg 2002;74:S1754-7; discussion S92-9.

14. Klieverik LMA, Yacoub MH, Edwards S, et al. Surgical Treatment of Active Native Aortic Valve Endocarditis With Allografts and Mechanical Prostheses. Ann Thorac Surg 2009;88:1814-21.

15. Byrne JG, Rezai K, Sanchez JA, et al. Surgical management of endocarditis: the society of thoracic surgeons clinical practice guideline. Ann Thorac Surg 2011;91:2012-9.

16. Chairs ASToIECGWC, Pettersson GB, Coselli JS, et al. 2016 The American Association for Thoracic Surgery (AATS) consensus guidelines: Surgical treatment of infective endocarditis: Executive summary. J Thorac Cardiovasc Surg 2017;153:1241-58.e29.

17. Savage EB, Saha-Chaudhuri P, Asher CR, et al. Outcomes and prosthesis choice for active aortic valve infective endocarditis: analysis of the Society of Thoracic Surgeons Adult Cardiac Surgery Database. Ann Thorac Surg 2014;98:806-14.

18. Jassar AS, Bavaria JE, Szeto WY, et al. Graft selection for aortic root replacement in complex active endocarditis: does it matter? Ann Thorac Surg 2012;93:480-7.

19. Romeo JLR, Takkenberg JJM, Roos-Hesselink JW, et al Outcomes of Pregnancy After Right Ventricular Outflow Tract Reconstruction With an Allograft Conduit. J Am Coll Cardiol 2018;71:2656-65.

20. Bekkers JA, Klieverik LM, Raap GB, et al. Re-operations for aortic allograft root failure: experience from a 21year single-center prospective follow-up study. Eur J Cardiothorac Surg 2011;40:35-42.

21. Kowert A, Vogt F, Beiras-Fernandez A, et al. Outcome after homograft redo operation in aortic position. Eur J Cardiothorac Surg 2012;41:404-8.

22. Musci $M$, Weng $Y$, Hübler $M$, et al. Homograft aortic root replacement in native or prosthetic active infective 
endocarditis: Twenty-year single-center experience. J

Thorac Cardiovasc Surg 2010;139:665-73.

23. Yankah AC, Klose H, Petzina R, et al. Surgical management of acute aortic root endocarditis with viable homograft: 13-year experience. Eur J Cardiothorac Surg 2002;21:260-7.

24. Perrotta S, Jeppsson A, Fröjd V, et al. Surgical Treatment of Aortic Prosthetic Valve Endocarditis: A 20-Year SingleCenter Experience. Ann Thorac Surg 2016;101:1426-32.

25. Nappi F, Spadaccio C, Dreyfus J, et al. Mitral endocarditis: A new management framework. J Thorac Cardiovasc Surg 2018;156:1486-95.e4.

26. Olivito S, Lalande S, Nappi F, et al. Structural deterioration of the cryopreserved mitral homograft valve. J Thorac Cardiovasc Surg 2012;144:313-20, 20.e1.

27. Nappi F, Spadaccio C, Acar C. Use of allogeneic tissue to treat infective valvular disease: Has everything been said? J Thorac Cardiovasc Surg 2017;153:824-8.

28. Acar C. Monobloc or separate aortic and mitral homografts? J Thorac Cardiovasc Surg 2006;132:442-3; author reply 3 .

29. Lalani T, Chu VH, Park LP, et al. In-hospital and 1 -year mortality in patients undergoing early surgery for prosthetic valve endocarditis. JAMA Intern Med 2013;173:1495-504.

30. Steffen V, Marsch G, Burgwitz K, et al. Resistance to infection of long-term cryopreserved human aortic valve allografts. J Thorac Cardiovasc Surg 2016;151:1251-9.

31. Camiade C, Goldschmidt P, Koskas F, et al. Optimization of the Resistance of Arterial Allografts to Infection: Comparative Study with Synthetic Prostheses. Ann Vasc Surg 2001;15:186-96.

32. Kuehn C, Graf K, Mashaqi B, et al. Prevention of early vascular graft infection using regional antibiotic release. J Surg Res 2010;164:e185-91.

33. Zander J, Maier B, Zoller M, et al. Effects of biobanking conditions on six antibiotic substances in human serum assessed by a novel evaluation protocol. Clin Chem Lab Med 2016;54:265-74.

34. Klieverik LM, Takkenberg JJ, Bekkers JA, et al. The Ross operation: a Trojan horse? Eur Heart J 2007;28:1993-2000.

35. Reece TB, Welke KF, O'Brien S, et al. Rethinking the ross procedure in adults. Ann Thorac Surg 2014;97:175-81.

36. Mazine A, El-Hamamsy I, Verma S, et al. Ross Procedure in Adults for Cardiologists and Cardiac Surgeons: JACC Stateof-the-Art Review. J Am Coll Cardiol 2018;72:2761-77.

37. El-Hamamsy I, Willerson JT, Yacoub MH. Preserved homograft function 32 years after surgery in a young patient. J Thorac Cardiovasc Surg 2010;139:e141-2.

38. Mazine A, David TE, Rao V, et al. Long-Term Outcomes of the Ross Procedure Versus Mechanical Aortic Valve Replacement: Propensity-Matched Cohort Study. Circulation 2016;134:576-85.

39. Ratschiller T, Sames-Dolzer E, Paulus P, et al. Longterm Evaluation of the Ross Procedure in Acute Infective Endocarditis. Semin Thorac Cardiovasc Surg 2017. [Epub ahead of print].

40. Chiang YP, Chikwe J, Moskowitz AJ, et al. Survival and long-term outcomes following bioprosthetic vs mechanical aortic valve replacement in patients aged 50 to 69 years. JAMA 2014;312:1323-9.

41. Moon MR. Prosthetic valve selection in patients with leftsided endocarditis: bioprosthetic or mechanical valves? Curr Opin Cardiol 2014;29:127-32.

42. Foroutan F, Guyatt GH, O'Brien K, et al. Prognosis after surgical replacement with a bioprosthetic aortic valve in patients with severe symptomatic aortic stenosis: systematic review of observational studies. BMJ 2016;354:15065.

43. Wang M, Furnary AP, Li HF, et al. Bioprosthetic Aortic Valve Durability: A Meta-Regression of Published Studies. Ann Thorac Surg 2017;104:1080-7.

44. Bourguignon T, Bouquiaux-Stablo AL, Candolfi P, et al. Very long-term outcomes of the Carpentier-Edwards Perimount valve in aortic position. Ann Thorac Surg 2015;99:831-7.

45. Johnston DR, Soltesz EG, Vakil N, et al. Long-term durability of bioprosthetic aortic valves: implications from 12,569 implants. Ann Thorac Surg 2015;99:1239-47.

46. Attias D, Nejjari M, Nappi F, et al. How to treat severe symptomatic structural valve deterioration of aortic surgical bioprosthesis: transcatheter valve-in-valve implantation or redo valve surgery? Eur J Cardiothorac Surg 2018;54:977-85.

47. Glaser N, Franco-Cereceda A, Sartipy U. Late survival after aortic valve replacement with the perimount versus the mosaic bioprosthesis. Ann Thorac Surg 2014;97:1314-20.

48. Senage T, Le Tourneau T, Foucher Y, et al. Early structural valve deterioration of Mitroflow aortic bioprosthesis: mode, incidence, and impact on outcome in a large cohort of patients. Circulation 2014;130:2012-20.

49. Goldman S, Cheung A, Bavaria JE, et al. Midterm, multicenter clinical and hemodynamic results for the Trifecta aortic pericardial valve. J Thorac Cardiovasc Surg 2017;153:561-9.e2.

50. Kalra A, Rehman H, Ramchandani M, et al. Early 
Trifecta valve failure: Report of a cluster of cases from a tertiary care referral center. J Thorac Cardiovasc Surg 2017;154:1235-40.

51. Pfeiffer S, Santarpino G, Fischlein T. Stentless pericardial valve for acute aortic valve endocarditis with annular destruction. J Cardiovasc Med (Hagerstown) 2015;16:318-9.

52. Miceli A, Croccia M, Simeoni S, et al. Root replacement with stentless Freestyle bioprostheses for active endocarditis: a single centre experience. Interact Cardiovasc Thorac Surg 2013;16:27-30.

53. Nguyen DT, Delahaye F, Obadia JF, et al. Aortic valve replacement for active infective endocarditis: 5-year survival comparison of bioprostheses, homografts and mechanical prostheses 2 . Eur J Cardiothorac Surg 2010;37:1025-32.

54. Kim JB, Ejiofor JI, Yammine M, et al. Surgical outcomes of infective endocarditis among intravenous drug users. J Thorac Cardiovasc Surg 2016;152:832-41.e1.

55. Gupta P, McCormack DJ, Szczeklik M, et al. Infected calcified homograft root: a sutureless solution. Ann Thorac Surg 2013;95:1789-91.

56. Fischlein T, Meuris B, Hakim-Meibodi K, et al. The sutureless aortic valve at 1 year: A large multicenter cohort study. J Thorac Cardiovasc Surg 2016;151:1617-26.e4.

57. Kocher AA, Laufer G, Haverich A, et al. One-year outcomes of the Surgical Treatment of Aortic Stenosis With a Next Generation Surgical Aortic Valve (TRITON) trial: a prospective multicenter study of rapid-deployment aortic valve replacement with the EDWARDS INTUITY Valve System. J Thorac Cardiovasc Surg 2013;145:110-5; discussion 115-6.

58. Manne MB, Shrestha NK, Lytle BW, et al. Outcomes after surgical treatment of native and prosthetic valve infective endocarditis. Ann Thorac Surg 2012;93:489-93.

59. Grubitzsch H, Schaefer A, Melzer C, et al. Outcome after surgery for prosthetic valve endocarditis and the impact of preoperative treatment. J Thorac Cardiovasc Surg 2014;148:2052-9.

60. Mayer K, Aicher D, Feldner S, et al. Repair versus replacement of the aortic valve in active infective endocarditis. Eur J Cardiothorac Surg 2012;42:122-7.

61. David TE. Aortic valve repair for active infective

Cite this article as: Nappi F, Singh SSA, Spadaccio C, Acar C. Revisiting the guidelines and choice the ideal substitute for aortic valve endocarditis. Ann Transl Med 2020;8(15):952. doi: 10.21037/atm-20-1522 endocarditis. Eur J Cardiothorac Surg 2012;42:127-8.

62. Nappi F. CRT-721 The Cryopreserved Mitral Homograft Valve: 19 Years Experience. JACC Cardiovasc Interv 2014;7:S58.

63. Hussain ST, Blackstone EH, Pettersson GB. Allografts remain a cornerstone of surgical treatment of invasive and destructive aortic valve infective endocarditis: Surgeon and technique do matter! J Thorac Cardiovasc Surg 2017;154:1900-1.e1.

64. Nappi F, Spadaccio C. keep fumbling around in the dark when it comes to infective endocarditis, or produce new, reliable data to redesign the guidelines? J Thorac Cardiovasc Surg 2018;155:75-6.

65. Akins CW, Miller DC, Turina MI, et al. Guidelines for reporting mortality and morbidity after cardiac valve interventions. Ann Thorac Surg 2008;85:1490-5.

66. Yacoub MH, El-Hamamsy I. Valvular disease: The private life of tissue valves. Nat Rev Cardiol 2010;7:424-6.

67. Smith JD, Ogino H, Hunt D, et al. Humoral immune response to human aortic valve homografts. Ann Thorac Surg 1995;60:S127-30.

68. Martin E, Mohammadi S, Jacques F, et al. Clinical Outcomes Following the Ross Procedure in Adults: A 25-Year Longitudinal Study. J Am Coll Cardiol 2017;70:1890-9.

69. Nappi F, Spadaccio C, Al-Attar N, et al. The Ross procedure at the crossroads: lessons from biology: is Dr Ross's dream concluded? Int J Cardiol 2015;178:37-9.

70. Spadaccio C, Montagnani S, Acar C, et al. Introducing bioresorbable scaffolds into the show. A potential adjunct to resuscitate Ross procedure. Int J Cardiol 2015;190:50-2.

71. Helder MRK, Kouchoukos NT, Zehr K, et al. Late durability of decellularized allografts for aortic valve replacement: A word of caution. J Thorac Cardiovasc Surg 2016;152:1197-9.

72. da Costa FD, Costa AC, Prestes R, et al. The early and midterm function of decellularized aortic valve allografts. Ann Thorac Surg 2010;90:1854-60.

73. Helder MR, Hennessy RS, Spoon DB, et al. Low-Dose Gamma Irradiation of Decellularized Heart Valves Results in Tissue Injury In Vitro and In Vivo. Ann Thorac Surg 2016;101:667-74. 
Table S1 Studies reporting long term outcomes of biological substitute in aortic valve endocarditis $(74,75)$

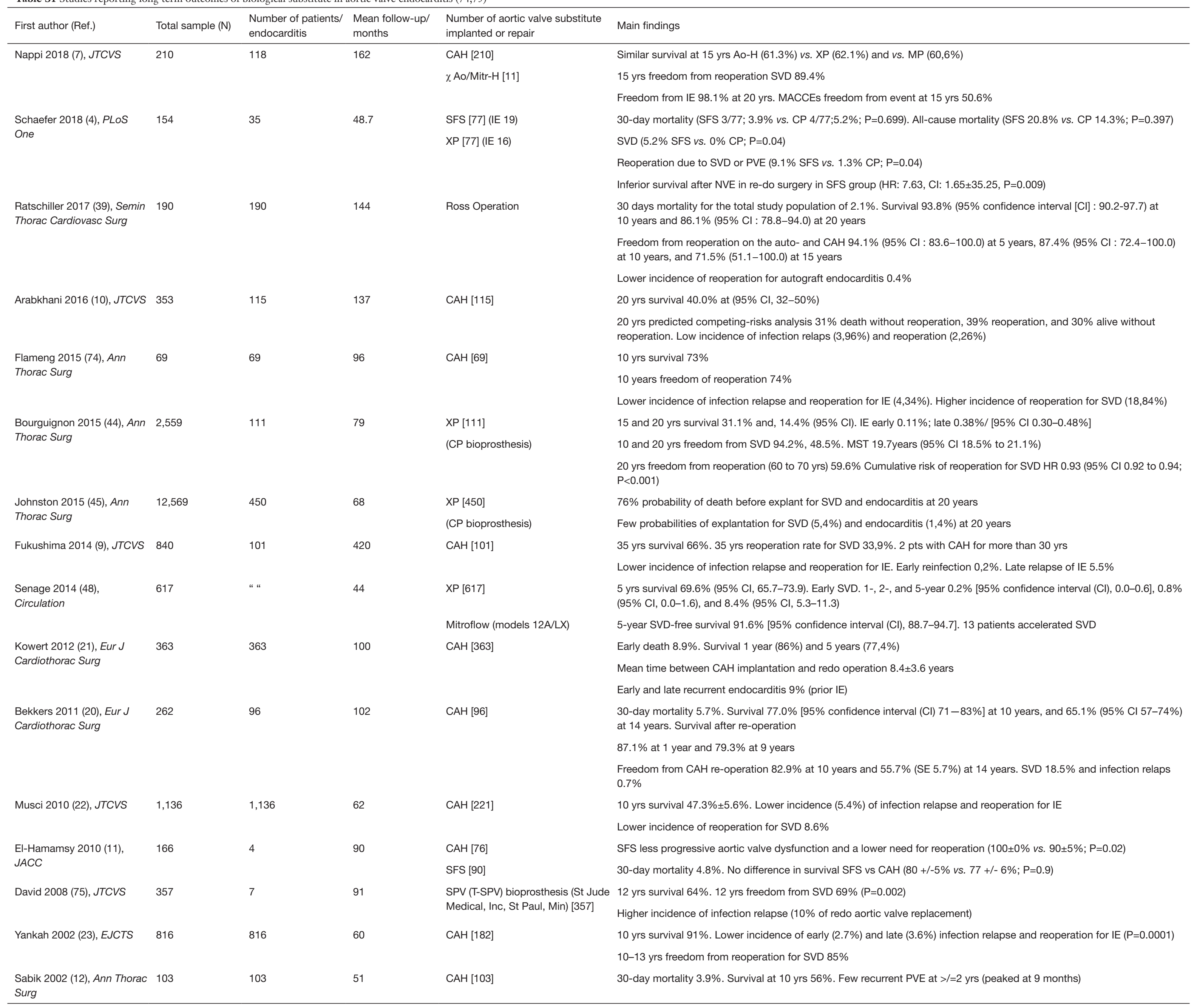


Table S2 Studies comparing long term outcomes of allogenic and autologous with conventional prostheses

\begin{tabular}{|c|c|c|c|c|c|}
\hline First author (Ref.) & Total sample (N) & $\begin{array}{l}\text { Number of patients/ } \\
\text { endocarditis }\end{array}$ & $\begin{array}{l}\text { Mean follow-up/ } \\
\text { months }\end{array}$ & $\begin{array}{l}\text { Number of aortic valve } \\
\text { substitute implanted or repair }\end{array}$ & Main findings \\
\hline \multirow[t]{3}{*}{ Kim 2016 (8) JTCVS } & \multirow[t]{3}{*}{304} & \multirow[t]{3}{*}{304} & \multirow[t]{3}{*}{29.4} & $\mathrm{CAH}[86]$ & $\begin{array}{l}\text { Similar survival between valve substitute. Odds ratio 1.61; } 95 \% \text { confidence interval }(\mathrm{Cl}), 0.73-3.40, \mathrm{P}=0.23 \text { (HR 1.10; 95\% } \\
\mathrm{Cl}, 0.62-1.94, \mathrm{P}=0.75 \text { ) }\end{array}$ \\
\hline & & & & MP [79] & \multirow{2}{*}{$\begin{array}{l}\text { Reinfection } 7.7 \% \text {. No difference in freedom from reinfection rates }(\mathrm{P}=.65) \text {. CAH did not significantly affect reinfection (HR } \\
1.04 ; 95 \% \mathrm{Cl}, 0.49-2.18, \mathrm{P}=0.93)\end{array}$} \\
\hline & & & & $\mathrm{XP}$ [139] & \\
\hline \multirow[t]{3}{*}{ Kim 2016 (54) JTCVS } & \multirow[t]{3}{*}{436} & \multirow{3}{*}{$\begin{array}{l}\text { IVDU } 78 \\
\text { Non-IVDU } 358\end{array}$} & \multirow[t]{3}{*}{29.4} & $\mathrm{CAH}[86]$ & Similar survival between group (IVDU vs. Non IDVU). (HR, $0.78 ; 95 \% \mathrm{Cl}, 0.44-1.37)$. No difference between valve substitute \\
\hline & & & & MP [99] & Lower operative mortality in IVDUs [odds ratio, $0.25 ; 95 \%$ confidence interval (CI), $0.06-0.71$ ] \\
\hline & & & & $\mathrm{XP}[206]$ & $\begin{array}{l}\text { Better valve-related complications in IVDUs ( } \mathrm{HR}, 3.82 ; 95 \% \mathrm{Cl}, 1.95-7.49 ; \mathrm{P}<0.001) \text { for higher rates of reinfection (HR, 6.20; } \\
95 \% \mathrm{Cl}, 2.56-15.00 ; \mathrm{P}<0.001)\end{array}$ \\
\hline \multirow{3}{*}{$\begin{array}{l}\text { Perrotta } 2016 \text { (24) Ann } \\
\text { Thorac Surg }\end{array}$} & \multirow[t]{3}{*}{84} & \multirow[t]{3}{*}{84} & \multirow[t]{3}{*}{65} & $\mathrm{CAH}[56]$ & 10 yrs similar survival. CAH $58 \%$ vs. conventional prosthesis $75 \%(P=0.17)$ \\
\hline & & & & MP [20] & \multirow{2}{*}{$\begin{array}{l}\text { Higher incidence of reoperation for infection relaps in MP or XP (12.9\%) than Ao-H (0\%) }(P=0.006) \text {. Lower incidence of } \\
\text { reoperation for SVD in CAH at } 10 \text { yrs }(5.3 \%)\end{array}$} \\
\hline & & & & $X P$ [12] & \\
\hline \multirow[t]{3}{*}{ Chiang 2014 (40) JAMA } & \multirow[t]{3}{*}{2002} & \multirow[t]{3}{*}{16} & \multirow[t]{3}{*}{128} & MP [9] & No difference in 30-day mortality XP (3\%) vs. MP $(3 \%)(P=0.49)$ \\
\hline & & & & $\mathrm{XP}[7]$ & $\begin{array}{l}\text { No difference survival (P=0.74); 15-year survival XP (60.6\%, 95\% Cl, 56.3-64.9\%) vs. MP (62.1\%, 95\% Cl, 58.2-66.0\%). } \\
\text { HR } 0.97 \text { ( } 95 \% \mathrm{Cl}, 0.83-1.14)\end{array}$ \\
\hline & & & & & 15 yrs reoperation XP (12.1\%) vs. MP (6.9\%) (95\% Cl, 8.8-15.4\% vs. $95 \% \mathrm{Cl}, 4.2-9.6 \% . \mathrm{HR}: 0.52 ; 95 \% \mathrm{Cl}, 0.36-0.75)$ \\
\hline \multirow[t]{3}{*}{ Hussain 2014 (63) JTCVS } & \multirow[t]{3}{*}{775} & \multirow[t]{3}{*}{537} & \multirow[t]{3}{*}{84} & $\mathrm{CAH}[357]$ & \multirow{3}{*}{$\begin{array}{l}30 \text { days mortality } 7 \% \text { for aortic valve and } 14 \% \text { for aortic and mitral valve IE. Survival at } 5 \text { years } 75 \% \text {. Rate of recurrence of } \\
\text { infection } 5.1 \%\end{array}$} \\
\hline & & & & MP [25] & \\
\hline & & & & $\mathrm{XP}$ [139] & \\
\hline \multirow[t]{3}{*}{ Grubitzsch 2014 (59) JTCVS } & \multirow[t]{3}{*}{149} & \multirow[t]{3}{*}{96} & \multirow[t]{3}{*}{48} & MP [11] & Early death $31.5 \%$. Late death $7.38 \%$ \\
\hline & & & & XP [80] & Overall and event-free survivals at 10 years were $75 \%+/-3.8 \%$ and $64 \% 4.0 \%$ \\
\hline & & & & Ross Procedure [5] & Freedom from recurrent infection and reoperation at 10 years were $81 \%+/-3.6 \%$ and $91 \%+/-2.6 \%$ \\
\hline Manne 2012 (58) Ann Thorac & 428 & 282 & 12 & $\mathrm{CAH}[173]$ & Higher 30 -day mortality PVE vs. NVE (13\% versus $5.6 \%$; $P<0.01)$ \\
\hline & & & & MP [24] & No difference in survival NVE vs. PVE ( $35 \%$ versus $29 \% ; \mathrm{P}=0.19$ ) \\
\hline & & & & XP [84] & $\begin{array}{l}\text { Higher } 30 \text { days mortality and } 1 \text { year mortality for Staphylococcus aureus infection (15\% versus } 8.4 \% ; \mathrm{P}<0.05) \text { and }(28 \% \\
\text { versus } 18 \% ; \mathrm{P}=0.02)\end{array}$ \\
\hline & & & & Ross operation [1] & Few reoperation for persistent infection or relapse $(2.4 \%)$ \\
\hline & & & & Ao-R [12] & \\
\hline Mayer 2012 (60) Eur J & 100 & 100 & 31 & MP [10] & Similar 30-day mortality Ao-R 9\% vs. Ao-Rpl $18 \%(P=0.37)$. Better survival Ao-R ( $88 \%)$ vs. Ao-Rpl $(65 \%)(P=0.047)$ \\
\hline Cardiothorac Surg & & & & XP [51] & Higher rate of reoperation Ao- $\mathrm{R}(35 \%)$ vs. Ao- $\mathrm{Rpl}(10 \%)(\mathrm{P}=0.021)$ \\
\hline & & & & Ross operation [6] & \\
\hline & & & & Ao-R [33] & \\
\hline Nguyen 2010 (53) Eur $J$ & 167 & 167 & 60 & CAH [77] & 30 day mortality XP (19.4\%), Ao-H (7.4\%), MP (10.1\%) (P=0.27) \\
\hline Cardiothorac Surg & & & & MP [109] & XP lower overall 5-year survival $</=65$ yrs [adjusted HR $4.14(1.27-13.45), P=0.018$ ] but not $>65$ yrs [adjusted HR: 1.45 \\
\hline & & & & XP [31] & (0.35-5.97), P=0.60]. No difference between CAH and MP [HR (0.46,95\% Cl (0.15-1.42), P=0.18] \\
\hline Klieverik 2009 (14) Ann & 138 & 138 & 96 & $\mathrm{CAH}[106]$ & Higher 30-day mortality for $\mathrm{CAH}(\mathrm{P}=0.25)$. No difference in survival at $15 \mathrm{yrs}$ ( $\mathrm{Ao}-\mathrm{H} 59 \% \pm 6 \%$ and MP $66 \% \pm 9 \%(P=0.68)$ \\
\hline Thorac Surg & & & & MP [32] & and freedom from recurrent infection $(P=0.29)$. Higher rates of reoperation for $\mathrm{CAH}(\mathrm{P}=0.02)$ \\
\hline David 2007 (2) JTCVS & 383 & 383 & 73 & $\mathrm{CAH}[18]$ & 15 yrs survival $44 \%$. Relapse of IE independent predictors of death (HR 2.2, 95\% Cl 1.2-3.9) \\
\hline & & & & MP [214] & 15 yrs freedom from recurrent IE $86 \%$ for all patients without difference between type of valve implanted \\
\hline & & & & $\mathrm{XP}$ [133] & 15 yrs freedom from reoperation $70 \%$ \\
\hline Moon 2001 (3) Ann Thorac & 306 & 306 & 183 & CAH [20] & 20 years survival $46 \% \mathrm{MP}, 41 \%, \mathrm{XP}, 58 \% \mathrm{CAH} ; \mathrm{P}>0.27$ \\
\hline Surg & & & & MP [65] & $\begin{array}{l}\text { Lower risk of infection relapse without group difference. } 5 \text { years } 2.1 \% \mathrm{MP}, 2.3 \% \mathrm{XP} \text {, and } 3.6 \% \mathrm{Ao}-\mathrm{H} ; \mathrm{P}>0.88 \text {. After } 5 \text { years } \\
0.5 \% \text { mechanical prosthesis, } 1.1 \% \text { stented xenograft and } 3.1 \% \mathrm{CAH} ; \mathrm{P}>0.25\end{array}$ \\
\hline & & & & XP [221] & $\begin{array}{l}10 \text { and } 15 \text { yrs freedom from reoperation for MP } 74,6 \% ; 10 \text { and } 15 \text { yrs freedom from reoperation for XP } 56.6 \%, 22.6 \% \\
P>0.64\end{array}$ \\
\hline
\end{tabular}

\section{References}

74. Flameng W, Daenen W, Jashari R, et al. Durability of homografts used to treat complex aortic valve endocarditis. Ann Thorac Surg 2015;99:1234-8.

75. David TE, Feindel CM, Bos J, et al. Aortic valve replacement with Toronto SPV bioprosthesis: optimal patient survival but suboptimal valve durability. J Thorac Cardiovasc Surg 2008;135:19-24. 